\title{
Corporate Governance in European Listed Companies and Financial Institutions
}

\author{
By Vicenç Ribas-Ferrer*
}

The article discusses corporate governance in listed companies and credit institutions from the perspective of European Union law. Recent legal evolution in listed companies' corporate governance deals mainly with the issues of transparency, the role of shareholders and investors, the duties and responsibilities of the board of directors and the management compensation. Progress has been made with the specific principles of corporate governance for banking and other financial institutions, and with the duties and functioning of the board, risk management and remuneration policies.

Keywords: European Union. Corporate governance. Listed companies. Financial institutions. Shareholder involvement. Board of directors. Risk management. Remuneration policies.

\section{Introduction}

\section{Concept and Problems}

Corporate governance has become a major concern in the fields of both corporate and financial law. Since the economic and financial crisis the subject is usually in the centre of any reform in both subjects. Corporate governance is a matter that has been largely discussed since the eighties and clearly established in the academy and business practice since the nineties. ${ }^{1}$ From the law perspective, the concept of corporate governance is understood as a set of principles and rules related with the management of the corporate entities. ${ }^{2}$ Listed corporations, banks and other financial institutions are paradigms of this category.

The scope of problems falling into its governance is becoming vast and complex. Traditional problems such as different systems of control of a

\footnotetext{
${ }^{*}$ Professor of Commercial and Corporate Law, Universidad de Alcalá, Spain.

${ }^{1}$ Probably the most well known controversy on the matter has taken place in the United States during the working out of the Principles of Corporate Governance promoted, adopted and promulgated by the American Law Institute (May, 1992) and edited by the American Law Institute Publishers (vol. I, 432 pp. and vol. II, 477 pp.), 1994. However, the most likely top cited pioneering and influential major work is the Cadbury Report 1992, (91 pp.) followed by the The Code of Best Practice (12 pp.). See Weil, Gostshal \& Manges 2002 (§III.A) for a comparison of different definitions in the European area. Form the European Union perspective, see European Commission COM 2003 (\$3.1), European Commission COM 2011 (Preamble, p. 1) and European Commission COM 2012 (\$1).

${ }^{2}$ Cfr. the definition from the Cadbury Report 1992 (\$2.5) emphasizing that "[c]orporate governance is the system by which companies are directed and controlled" with the OECD 2004 (p. 11) when it says that "[c]orporate governance involves a set of relationships between a company's management, its board, its shareholders and other stakeholders".
} 
corporation like majority control, control through a legal device (i.e., pyramiding), minority control or management control, all have relevance today. ${ }^{1}$ From general aspects like the object and conduct of the corporation and the functions and duties of the board and the management, to the internal structure of the financial institutions and the relationships between financial institution and its stakeholders, there is still a large bundle of open questions. ${ }^{2}$ But probably the economic and financial crisis has done its work to renew old and new problems. On the one hand, there have been shortcomings in the functioning of listed companies' corporate governance, reaffirming that the participation of shareholders is not an effective means of control and accountability of managers. ${ }^{3}$ On the other hand, the corporate governance of financial institutions has played an important role in the crisis, mainly due to the accumulation of excessive risks. ${ }^{4}$

\section{Corporate Governance in Europe}

The European Union (EU) addresses the corporate governance approach from two main ideas: efficiency and competitiveness of businesses and to rebuilding European investor confidence. ${ }^{5}$ Firstly, well managed companies, with strong corporate governance records outperform their competitors. And secondly, the strengthening of shareholders' rights and third parties protection will contribute to investor confidence. Well-managed companies are essential to deepen the internal market and make an essential contribution to the integration of the European capital market.

The EU has been concerned about three major subjects. ${ }^{6}$ Firstly, enhancing corporate governance disclosure. ${ }^{7}$ Secondly, the EU pays attention to

\footnotetext{
${ }^{1}$ Following Berle \& Means 1932 (pp. 70-90). Their position about the large company remains illustrative: "the community [is placed] in a position to demand that the modern corporation serve not alone the owners or the control but all society" (id., p. 356).

${ }^{2}$ Cfr. American Law Institute 1994 (§§ 2.01-V) with European Commission COM 2010 (§2). For a modern approach, see, for example, the recent Basel Committee's revised principles, BIS 2015 , and its emphasis on the critical importance of effective corporate governance for the safe and sound functioning of banks.

${ }^{3}$ Considering the passive attitude of shareholders and the short time of possession of the shares, the system in which is based the structure of the corporation have a limited effectiveness. See European Commission COM 2012 (§3) when it says that [e]ffective, sustainable shareholder engagement is one of the cornerstones of listed companies' corporate governance model and demands better shareholder oversight of remuneration policy and better shareholder oversight of related party transactions. About the collective action problem, see Weil, Gostshal \& Manges 2002 (§III.B).

${ }^{4}$ See Iglesias-Rodriguez 2015.

5 European Commission COM 2003 (pp. 3, 7, 8, 9 \& 12), European Commission Recommendation 2004 (Preamble $\S 3 \& 6)$, European Commission COM 2011 (Preamble), European Commission Recommendation 2014 (Preamble §1): "Good corporate governance is first and foremost the responsibility of the company concerned, and rules at European and national level are in place to ensure that certain standards are respected".

${ }^{6}$ For a wider approach, see Ribas-Ferrer 2014. Also see Winter Report 2002 (\$§2-6). See European Commission COM 2011 (Question 2), about corporate governance for unlisted companies.

${ }^{7}$ See infra $\$ 3.1-2$.
} 
enhancing effective shareholder control and participation, particularly promoting the effective exercise of shareholders' rights in listed companies and monitoring conflicts of interests and the remuneration policies. ${ }^{1}$ And thirdly, the EU has decided to modernize the board of directors with regards to composition, remuneration and the responsibility of directors. ${ }^{2}$

\section{Corporate Governance in Listed Companies}

\section{Disclosure}

Disclosure issues have crystallized in the requirements included in two annual reports. Firstly, listed companies shall incorporate a corporate governance statement in their annual management report (the Annual Corporate Governance Statement). ${ }^{3}$ Secondly, it has been proposed that companies must write a remuneration report corresponding a period of the last financial year, in a form that must be "clear and understandable" for any reader, and should contain a "comprehensive overview of the remuneration"; the report should include all kind of benefits "granted to individual directors". 4 Finally, institutional investors should disclose their investment policy and their policy with respect to the exercise of voting rights in companies in which they invest. ${ }^{5}$

\section{Shareholder's Participation and Control}

The second major issue in corporate governance in listed companies is shareholder participation and control. Firstly, strengthening shareholders' rights in access to information, participation and voting in the general meeting. ${ }^{6}$ Secondly, guaranteeing shareholders the right to vote on the remuneration policy and on the remuneration report. ${ }^{7}$ Thirdly, proposing measures addressed to institutional investors and asset managers to work out a sound policy on shareholder engagement; institutional investors are asked to

\footnotetext{
${ }^{1}$ See infra $\$ \$ 3.2 \& 3.4$.

${ }^{2}$ See infra $\$ 3.3$.

${ }^{3}$ European Union Directive 2013a ( $\left.\$ 20 \& 34.1\right)$, European Commission COM 2003 (\$3.1.1). See also European Commission Recommendation 2014 (Preamble $\S 8,16-17$; $\S 3-4,6,8-10$ ), European Commission COM 2012 (\$2.2), European Commission COM 2011 (\$3.1),

${ }^{4}$ European Union Directive Proposal 2014 (\$1.4); European Commission Recommendation 2009 (§5), European Commission Recommendation 2004 (§3).

${ }^{5}$ European Union Directive Proposal 2014 (\$3), European Commission COM 2011 (§2.1), European Commission COM 2003 (\$3.1.1).

${ }^{6}$ European Union Directive Proposal 2014 (§1.3-4), European Commission COM 2012 (§23), European Commission COM 2011 (\$2), European Commission COM 2010 (\$5.5), European Union Directive 2007 (Preamble §3; §§6-14), European Commission COM 2003 $(\S 3.1 .2)$.

7 European Union Directive Proposal 2014 (§1.4), European Commission COM 2012 (§3), European Commission COM 2011 (\$1.4), European Commission COM 2010 (§3), European Commission Recommendation 2009b (\$2-3, 6), European Commission COM 2009 (§§I-II), European Commission Recommendation 2005 (§), European Commission Recommendation 2004 (§4), European Commission COM 2003 (§3.1.3).
} 
disclose to the public their equity investment strategy and also transparency is required for asset managers and proxy advisors. ${ }^{1}$

\section{Board of Directors}

The board and its directors are another area of deep concern. The board itself should carry out an annual performance evaluation and disclose adequate information about its internal organization and procedures. ${ }^{2}$ Nonexecutive directors should be selected on the basis of a broad set of criteria and qualifications, considering the supervisory role of the directors. ${ }^{3}$ Particularly, independent directors should be capable of challenging the decisions of management, being considered to be independent only if they are free of any business, family or any other relationship, with the company, its controlling shareholders or the management of either, that creates a conflict of interest such as to impair his or her judgement. ${ }^{4}$ Diversity in the board should be taken into account and a description of the diversity policy applied should be disclosed. ${ }^{5}$ Committees are required particularly in areas of conflicts of interest. ${ }^{6}$ The audit committee should be composed exclusively of nonexecutive directors, assisting the board and monitoring the external auditor. ${ }^{7} \mathrm{~A}$ recommended nomination committee composed of at least a majority of independent non-executive or supervisory directors should evaluate board candidates and review the policy of the board for selection and appointment of senior management. ${ }^{8}$ Finally, the remuneration policy for executive directors (covering share-based remuneration, and its implementation) must be periodically reviewed by the remuneration committee. ${ }^{9}$

\section{Directors' Remuneration}

Directors' remuneration involves the consideration of two main subjects. On the one side, information "detailed and user-friendly" on the individual remuneration of directors should be disclosed by listed companies. ${ }^{10}$ On the

\footnotetext{
${ }^{1}$ European Union Directive Proposal 2014 (§3), European Commission COM 2012 (\$2.4), European Commission COM 2011 (\$2.2-3), European Commission COM 2003 (\$3.1.1.).

${ }^{2}$ European Commission COM 2011 (§1.3), European Commission Recommendation 2005 (§89), European Commission COM 2003 (\$3.1.2.).

${ }^{3}$ European Commission COM 2011 (§1.1), European Commission Recommendation 2005 (§3$(\S 3-5,10-11)$.

${ }^{4}$ European Commission Recommendation 2005 (§13, Annex II), European Commission COM $2003(\$ 3.1 .3)$.

${ }^{5}$ European Union Directive 2014b (§1.2), European Union Directive 2013a (§20.a.1.g), European Commission COM 2012 (\$2.1), European Commission COM 2011 (\$1.1).

${ }^{6}$ European Commission Recommendation 2005 (§5-7), European Commission COM 2003 (§3.1.3).

${ }^{7}$ European Union Directive 2014a ( $\left.\$ 1.32\right)$, European Commission Recommendation 2005 ( $\$ 5-$ (§5-7, 11; Annex I.1.6, 4), European Commission COM 2003 (\$3.1.3).

${ }^{8}$ European Commission Recommendation 2005 (Annex I.2), European Commission COM $2003(\$ 3.1 .3)$.

${ }^{9}$ European Commission Recommendation 2009b (\$7-9), European Commission COM 2009 (§II), European Commission Recommendation 2005 (Annex I.3).

${ }^{10}$ European Union Directive Proposal 2014 (\$1.4), European Commission Recommendation 2009b (§2.2), European Commission Recommendation 2004 (§5).
} 
other hand, companies should explain with clear criteria for the award of fixed and, particularly, variable remuneration. In this field, the remuneration policy should reveal the performance criteria (financial and non-financial) to be used, the contribution to the long-term interests and sustainability of the company and the deferral periods and clawback provisions. ${ }^{1}$

\section{Corporate Governance in Financial Institutions}

\section{Financial Markets Singularities and Regulation}

Banks and other financial institutions have special characteristics that lead to a distinctive corporate governance system. Firstly, the nature of the activities and the interdependencies within the financial entities produces a systemic risk which may affect the stability of the financial system and led governments to provide public funding for the financial sector. ${ }^{2}$ Secondly, to further the interests of shareholders, corporate governance in the financial services sector shall consider the interests of other stakeholders (among others, savers, depositors, life insurance, etc). ${ }^{3}$ Meanwhile, shareholders are potentially risk takers because they benefit from the short term profits and rise of share price, the other stakeholders are expected to desire a low level of risk and long term decisions. New categories of shareholders showing little interest in long-term governance may encourage excessive risk-taking. ${ }^{4}$

The financial crisis showed failures in risk assessment and risk management. ${ }^{5}$ This situation was aggravated by the complexity of structures and products and the lack of effective control of corporate governance mechanisms. ${ }^{6}$ Neither the boards of directors and supervisory authorities, did have an accurate and acute understanding "on the nature or scale of the risks they were facing" nor the shareholders performed properly "their role as owners of the companies". ${ }^{7}$ Most of the incentive schemes and remuneration remuneration policies contributed to excessive risk-taking and rewarding short-term expansion of the volume of trades rather than the long-term profitability of investments to the detriment of credit quality and prudence. ${ }^{8}$

Due to the fact that regulation did not prevent the crisis, there was a necessity of a profound review of the regulatory policy of global financial services with the aim of protecting customers, financial stability, and the

\footnotetext{
${ }^{1}$ European Union Directive Proposal 2014 (§1.4), European Commission Recommendation 2009b ( $\$ 4)$, European Commission Recommendation 2004 (§6-7).

2 European Union Directive 2013b (Preamble §53), European Union Regulation 2013 (Preamble §113), European Commission COM 2010 (§1-2).

${ }^{3}$ European Commission COM $2010(\$ 2)$.

${ }^{4}$ European Commission COM $2010(\$ 3.5)$.

${ }^{5}$ Liikanen Report 2012 ( $\left.\$ 5.5 .5\right)$, De Larosière Report 2009 ( $\left.\S 122-124\right)$.

${ }^{6}$ See BIS 2015 ( $\left.\$ 5: 95-104\right)$.

7 European Commission COM 2011 (§2), European Commission COM 2010 (§1). De Larosière Report 2009 ( $\$ 23)$.

${ }^{8}$ Liikanen Report 2012 ( $\left.\$ 5.5 .5\right)$, De Larosière Report 2009 (\$24, 111-112, 117-121), Financial Stability Board 2009 (§1-2).
} 
sustainability of economic growth. Principles were not sufficiently precise, giving too much scope for interpretation, putting them into practice in a purely formal application with no real qualitative assessment. Among the main causes of the lack of effective implementation of corporate governance principles by financial institutions were "the non-binding nature of corporate governance codes and principles, the disregard of corporate governance by supervisory authorities, and the absence of deterrent penalties". ${ }^{1}$

\section{Sound Principles on Corporate Governance for Financial Institutions}

In the aftermath of the crisis there was a general recognition of a need for a new governance framework for the financial sector leading to the development of a strong corporate, supervisory and sanctioning regime. ${ }^{2}$ The basis of the new regime establishes that the management body should "define, oversee and be accountable for the implementation of the governance arrangements", ensuring an effective and prudent management, and "the prevention of conflicts of interest". ${ }^{3}$ The arrangements should comply with some fundamental principles. ${ }^{4}$ (a) The board of directors should have the entire "responsibility for the institution"; in its capacity, the management body should "approve and oversee the implementation of the institution's strategic objectives, risk strategy and internal governance". ${ }^{5}$ (b) The board of directors is is responsible for guaranteeing "the integrity of the accounting and financial reporting systems" of the institution. ${ }^{6}$ (c) The board of directors should supervise "the process of disclosure and communications". ${ }^{7}$ (d) The board of directors should supervise senior management in an effective. ${ }^{8}$ (e) The chairman of the board and the chief executive officer should not exercise simultaneously their functions, although there may be some exceptions when the institution provides a justification and the competent authorities authorises the situation. ${ }^{9}$

\section{Risk Management}

Financial institutions should have governance arrangements with a clear organizational structure. In this chapter, they have to define with transparency consistent lines of responsibility and also "to identify, manage, monitor and report the risks they are or might be exposed to". ${ }^{10}$ Internal control

\footnotetext{
${ }^{1}$ European Union Directive 2013b (Preamble §53), Liikanen Report 2012 (\$§5.5.5), European Commission COM 2010 (\$3.2), De Larosière Report 2009 (\$51). See BIS 2015 (§13:157-168).

${ }^{2}$ De Larosière Report 2009 ( $\left.\$ 83\right)$.

${ }^{3}$ European Union Directive 2013b (\$88.1), European Commission COM 2010 (§5.8). See BIS $2015(\$ 3: 80-86)$

${ }^{4}$ European Union Directive 2013b (§88.1). See BIS 2015 (§§1-13); TCH 2015 (§§1-16); EBA $2011(\S \S 1-33)$.

${ }^{5}$ See BIS $2015(\S 1: 23-46)$.

${ }^{6}$ See BIS 2015 (\$9:132-137; $\left.\$ 10: 138-142\right)$.

${ }^{7}$ See BIS $2015(\$ 12: 151-156)$.

${ }^{8}$ See BIS 2015 ( $\left.\$ 1: 45-46 ; \S 4: 87-94\right)$.

${ }^{9}$ European Union Directive $2013 \mathrm{~b}(\$ 88.1 . e)$

${ }^{10}$ European Union Directive 2013b $(\$ \S 3.1 .3,74)$, Liikanen Report $2012(\S \S 5.5 .5)$, European Commission COM 2010 (§5.2), De Larosière Report 2009 (§122). See BIS 2015 (§8:126-131).
} 
mechanisms and remuneration policies should be consistent with a sound and effective risk management. The board has a relevant role in the approving and reviewing of "the strategies and policies for taking up, managing, monitoring and mitigating the risks" in which the institution can be exposed to. ${ }^{1}$

In addition, significant institutions should establish a risk committee composed of non-executive directors; the members of the committee have to have an "appropriate knowledge, skills and expertise" in order "to fully understand and monitor the risk strategy and the risk appetite of the institution". ${ }^{2}$ The risk committee should advise and assist the board directors in in the supervision of the implementation of the risk strategy by senior management.

Financial institutions also should have a risk management function acting independently from the operational structure and with sufficient authority, "resources and access to the management body". ${ }^{3}$

\section{Composition and Functioning of the Board}

Directors of financial institutions in the performance of their duties are required to accomplish particular conditions of good repute, knowledge, skills and experience. ${ }^{4}$ For or all directors is needed a wide range of experience and an adequate collective knowledge and skills in order to be able to understand the activities of the institution, with particular emphasis of the main risks. Any of member of the board should have sufficient commitment and time to perform their functions, particularly ensuring that they devote sufficient time to risk issues. ${ }^{5}$ As a general rule, directors should have a limited number of directorships at the same time and unless there is an exception, they should hold one of the combinations statutorily required: "one executive directorship with two non-executive directorships" or "four non-executive directorships". ${ }^{6}$ In order to foster alternative and critical thinking and independent opinions in the board, it is a requirement that the directors should "act with honesty, integrity and independence of mind". ${ }^{7}$ The rule intends to tackle in an independent way, when appropriate, the decisions of the senior management, assessing and challenging his opinions and performance and control the management decision-making. ${ }^{8}$

\footnotetext{
${ }^{1}$ European Union Directive 2013b (\$76.1-2). See BIS 2015 ( $\left.\$ 1: 23-46\right)$. See also European Union Regulation 2013 ( $\$ 189)$, when says that "all material aspects of the rating and estimation processes must be approved by the institution's management body or a designated committee thereof and senior management". See BIS 2015 (\$7:112-125).

${ }^{2}$ European Union Directive 2013b (\$76.3). See BIS 2015 ( $\left.\$ 3: 71-75\right)$.

${ }^{3}$ European Union Directive 2013b (\$76.5), European Commission COM 2010 (§5.2). See BIS 2015 (§6:105-111).

${ }^{4}$ European Union Directive 2013b (\$91.1, 7, 9-10\&12b), European Commission COM 2010 (§5.1), De Larosière Report 2009 (\$64.1). See BIS 2015 (\$2:47-56).

${ }^{5}$ European Union Directive 2013b (\$\$76.2, 91.2\&12a), European Commission COM 2010 $(\S 5.1)$

${ }^{6}$ European Union Directive 2013b ( $\left.\S 91.3-6\right)$, European Commission COM 2010 (§5.1).

${ }^{7}$ European Union Directive 2013b (\$91.8\&12c), OECD 2004 (§VI.E).

${ }^{8}$ European Union Directive 2013b (§91.8\&12c), OECD 2004 (§VI.E).
} 
Financial institutions which are significant in size, internal organisation and complexity of their activities should establish a nomination committee. ${ }^{1}$ The committee should be composed of non-executive directors being able to use any resources that they consider to be appropriate (in which sense the law allows to include external advice if necessary) and also the committee should receive proper funding. ${ }^{2}$ Broad functions are recognized to the nomination committee; among others, the committee have to asses candidates for the vacancies of the board of directors, and to evaluate the "knowledge, skills, diversity and experience of the management body". ${ }^{3}$

Financial institutions should annually disclose and update relevant information about governance arrangements. ${ }^{4}$ Amongst other responsibilities, they have to unveil "the number of directorships held by members of the management body", "the recruitment policy for the selection of members of the management body and their actual knowledge, skills and expertise". 5

\section{Remuneration Policies}

In the aftermath of the financial crisis the EU was convinced of the need for a mandatory regime on remuneration policies and passed legislation. It was established a set of principles for sound compensation in order to make remuneration practices compatible with effective risk management. ${ }^{6}$ The new regime introduces express obligations for the ones "whose professional activities have a material impact on the risk profile" for credit institutions and investment firms. ${ }^{7}$ The categories of staff include all "material risk takers", which comprehend any person engaged in control functions, senior management or "any employee receiving total remuneration which takes them into the same remuneration bracket as senior management and risk takers". 8 Relevant information regarding those categories of risk takers in financial institutions should be disclosed in order to know not only the remuneration policies but its practice. ${ }^{9}$

The principles on sound compensation are based on two main ideas. Fist, that the remuneration policy will be consistent and will promote "sound and effective risk management", and second, that the level of risk-taking that can be supported by the remuneration policy cannot surpass "the level of tolerated risk of the institution". ${ }^{10}$ In addition, the remuneration policy will be consistent "with the long-term interests of the institution" as well as the business strategy

\footnotetext{
${ }^{1}$ European Union Directive 2013b (\$88.2), De Larosière Report 2009 (§64.1). See BIS 2015 $(\S 3: 77)$.

${ }^{2}$ European Union Directive 2013b (\$88.2).

${ }^{3}$ European Union Directive 2013b (\$88.2).

${ }^{4}$ European Union Regulation 2013 (\$435.2), Liikanen Report 2012 (§§5.5.5).

${ }^{5}$ European Union Regulation $2013(\$ 435.2)$.

${ }^{6}$ European Union Directive 2013b (Preamble $\left.\S \S 4 \& 62-63, \S \S 88\right)$, European Union Directive 2010 (Annex I), Financial Stability Board 2009 (§1\&9). BIS 2015 (§11:143-150).

${ }^{7}$ European Union Directive 2013b (Preamble $\left.§ 63 \& 83\right)$; (§§92-93).

${ }^{8}$ European Commission Delegated Regulation 2014 (\$\$2-5), European Union Directive $2013 \mathrm{~b}$ 2013b (\$92.2).

${ }^{9}$ European Union Regulation $2013(\$ 450.1)$.

${ }^{10}$ European Union Directive 2013 b (\$92.2.a).
} 
of the company, and its objectives and values. ${ }^{1}$ The remuneration policy also have to contain "measures to avoid conflicts of interest". ${ }^{2}$ The board of directors is responsible for approving the general principles of the remuneration and supervising its implementation; furthermore, the board have to review regularly the mentioned principles. ${ }^{3}$

The staff in control functions will have appropriate authority, remuneration and independence. ${ }^{4}$ The policy should distinguish criteria between fixed and variable remuneration. The first should consider "relevant professional experience and organisational responsibility"; the second, should reveal the performance of the staff, taking into account its sustainability, the involved risks and the "performance in excess of that required to fulfil the employee's job". 5 Additional principles are provided for institutions beneficiaries with exceptional government assistance. ${ }^{6}$

Significant financial institutions have to establish a remuneration committee composed by non executive directors being able to asses remuneration policies and practices with "competent and independent judgment". ${ }^{7}$ The committee works on a preparatory stage related to decisions regarding remuneration which have to be taken by the board of directors. ${ }^{8}$

National authorities have a relevant role in the oversight of remuneration policies. First, competent authorities should gather information required to the financial institutions and provide the EBA with that information. ${ }^{9}$ Amongst other information, they have to join information about individuals "that are remunerated EUR 1 million or more per financial year". ${ }^{10}$ Second, competent authorities shall review and evaluate the governance arrangements of institutions and the competence of members of the board of directors to perform their duties. ${ }^{11}$ Finally, when the variable remuneration is not consistent "with the maintenance of a sound capital base", national authorities should require to the financial institutions to limit variable remuneration. ${ }^{12}$

\section{Conclusions}

Recent developments in the field of listed companies' corporate governance shows significant progress in disclosure issues such as management and remuneration reports. However, a wide range of relevant

\footnotetext{
${ }^{1}$ European Union Directive 2013b (\$92.2.b).

${ }^{2}$ European Union Directive 2013b (\$92.2.b).

${ }^{3}$ European Union Directive $2013 b(\$ 92.2 . c-d)$.

${ }^{4}$ European Union Directive 2013b ( $\left.\$ 76.5 ; 92.2 . e\right)$.

${ }^{5}$ European Union Directive $2013 \mathrm{~b}(\$ 92.2 . \mathrm{g})$. A wide range of rules are established for variable variable remuneration (see id. \$94).

${ }^{6}$ European Union Directive 2013b (\$93). See BIS 2015 (\$3:76).

${ }^{7}$ European Union Directive 2013b (\$\$92.2.f; 95).

${ }^{8}$ European Union Directive 2013b (\$95.2).

${ }^{9}$ European Union Directive 2013b (\$75).

${ }^{10}$ European Union Directive 2013b (\$75.3).

${ }^{11}$ European Union Directive 2013b (\$98.7).

${ }^{12}$ European Union Directive 2013b ( $\left.\$ 104.1 . g ; 141.2 . b\right)$.
} 
subjects such as transparency on institutional investors, asset managers and proxy advisors, identification of shareholders, the right to vote on the remuneration policy and on related party transactions remain in the terrain of recommendations or proposals.

In contrast, much has been done in financial corporate governance regulation. Lessons learnt from the crisis were basically implemented by capital requirements regulation and directive (CRR and CRD IV) in 2013 in a complex and wide process that still has not finished yet. Focused on risk management and remuneration policies, the banking sector is taking major steps towards creating a sounder and safer financial system.

\section{References}

American Law Institute 1994. Principles of corporate governance: Analysis and Recommendations. Vols. I-II. American Law Institute Publishers. St. Paul: Minn.

Berle, A. \& G. Means 1932. The modern corporation and private property. NY, 1932; reprint ed., William S. Hein, 1992.

BIS 2015. Bank for International Settlements, Basel Committee on Banking Supervision, Guidelines: Corporate governance principles for banks. 13 July.

Cadbury Report 1992. Stock Exchange Financial Reporting Council, Report of the Committee on the Financial Aspects of Corporate Governance.

De Larosière Report 2009. European Commission, The High-Level Group chaired by Jacques de Larosière, Report on Financial Supervision in the EU.

EBA 2011. European Banking Authority. Guidelines on Internal Governance.

European Commission COM 1999. Communication from the Commission COM(1999)232. Implementing the framework for financial markets: action plan.

European Commission COM 2003. Communication from the Commission to the Council and the European Parliament. COM (2003) 284 final. Modernizing Company Law and Enhancing Corporate Governance in the European Union - A Plan to Move Forward.

European Commission COM 2009. Communication from the Commission accompanying Commission recommendation complementing recommendations 2004/913/EC and 2005/162/EC as regards the regime for the remuneration of directors of listed companies and Commission recommendation on remuneration policies in the financial services sector. $\operatorname{COM}(2009) 211$ final.

European Commission COM 2010. Green Paper: Corporate governance in financial institutions and remuneration policies. COM(2010) 284 final.

European Commission COM 2011. Green Paper: The EU corporate governance framework. $\operatorname{COM(2011)~} 164$ final.

European Commission COM 2012. Communication from the Commission. Action Plan: European company law and corporate governance - a modern legal framework for more engaged shareholders and sustainable companies. $\operatorname{COM}(2012) 740$ final.

European Commission Delegated Regulation 2014. Commission Delegated Regulation (EU) No 604/2014 of 4 March 2014 supplementing Directive 2013/36/EU of the European Parliament and of the Council with regard to regulatory technical standards with respect to qualitative and appropriate 
quantitative criteria to identify categories of staff whose professional activities have a material impact on an institution's risk profile.

European Commission Recommendation 2004. Commission Recommendation of 14 December 2004 fostering an appropriate regime for the remuneration of directors of listed companies (2004/913/EC).

European Commission Recommendation 2005. Commission Recommendation of 15 February 2005 on the role of non-executive or supervisory directors of listed companies and on the committees of the (supervisory) board.

European Commission Recommendation 2009a. Commission Recommendation of 30 April 2009 on remuneration policies in the financial services sector. (2009/384/EC).

European Commission Recommendation 2009b. Commission Recommendation of 30 April 2009 complementing Recommendations 2004/913/EC and 2005/162/EC as regards the regime for the remuneration of directors of listed companies. (2009/385/EC).

European Commission Recommendation 2014. Commission Recommendation of 9 April 2014 on the quality of corporate governance reporting ('comply or explain') (2014/208/EU).

European Union Directive 2007. Directive 2007/36/EC of the European Parliament and of the Council of 11 July 2007 on the exercise of certain rights of shareholders in listed companies.

European Union Directive 2010. Directive 2010/76/EU of the European Parliament and of the Council of 24 November 2010 amending Directives 2006/48/EC and 2006/49/EC as regards capital requirements for the trading book and for resecuritisations, and the supervisory review of remuneration policies.

European Union Directive 2013a. Directive 2013/34/EU of the European Parliament and of the Council of 26 June 2013 on the annual financial statements, consolidated financial statements and related reports of certain types of undertakings, amending Directive 2006/43/EC of the European Parliament and of the Council and repealing Council Directives 78/660/EEC and 83/349/EEC.

European Union Directive 2013b (CRD IV). Directive 2013/36/EU of the European Parliament and of the Council of 26 June 2013 on access to the activity of credit institutions and the prudential supervision of credit institutions and investment firms, amending Directive 2002/87/EC and repealing Directives 2006/48/EC and 2006/49/EC.

European Union Directive 2014a. Directive 2014/56/EU of the European Parliament and of the Council of 16 April 2014 amending Directive 2006/43/EC on statutory audits of annual accounts and consolidated accounts.

European Union Directive 2014b. Directive 2014/95/EU of the European Parliament and of the Council of 22 October 2014 amending Directive 2013/34/EU as regards disclosure of non-financial and diversity information by certain large undertakings and groups.

European Union Directive Proposal 2014. Proposal for a Directive of the European Parliament and the Council amending Directive 2007/36/EC as regards the encouragement of long-term shareholder engagement and Directive 2013/34/EU as regards certain elements of the corporate governance statement, COM/2014/0213 final.

European Union Regulation 2013 (CRR). Regulation (EU) No 575/2013 of the European Parliament and of the Council of 26 June 2013 on prudential requirements for credit institutions and investment firms and amending Regulation (EU) No 648/2012. 
Financial Stability Board 2009. Financial Stability Board, Principles for Sound Compensation Practices.

Iglesias-Rodriguez 2015. Building Responsive and responsible financial regulators in the aftermath of the global financial crisis. Cambridge: Intersentia.

Liikanen Report 2012. European Commission, The High-level Expert Group chaired by Erkki Liikanen. Report on reforming the structure of the EU banking sector.

OECD 2004. Organization for Economic and Co-operation and Development, Principles of Corporate Governance.

Ribas-Ferrer 2014. Ribas-Ferrer, V. "El gobierno corporativo de las sociedades cotizadas y las entidades de crédito", Revista de Derecho Bancario y Bursátil 135: 261-340 (2014).

TCH 2015. The Clearing House Association, Guiding Principles for Enhancing U.S. Banking Organization Corporate Governance.

Weil, Gostshal \& Manges 2002. Comparative Study of Corporate Governance Codes Relevant to the European Union And Its Member States, On behalf of the European Commission, Internal Market Directorate General.

Winter Report 2002. European Commission, The High Level Group of Company Law Experts chaired by Jaap Winter, Report on a Modern Regulatory Framework for Company Law in Europe. 